\title{
Opsonic requirements and surface hydrophobicity of novobiocin-resistant, coagulase-negative staphylococci
}

\author{
L. MARODI*, PÁLMA BURJÁN and F. ROZGONYI†
}

Departments of Pediatrics and †Microbiology, University School of Medicine, Debrecen, H-4012 Debrecen, POB32, Hungary

\begin{abstract}
Summary. The opsonic requirement for phagocytosis and killing and cell-surface hydrophobicity of five strains of Staphylococcus saprophyticus isolated from clinical sources were studied. Phagocytosis and killing of bacteria by human granulocytes were measured in suspension. Bacterial aggregating cell-surface hydrophobicity was determined by salt aggregation, and the absorptive hydrophobicity was measured by hydrophobic interaction chromatography. All strains were well opsonised by pooled normal human serum $10 \%$. Ingestion of these bacteria could be detected to a variable extent in the absence of extracellular opsonins; heat-inactivated serum $10 \%$ or intravenous IgG concentrate $1 \mathrm{mg} / \mathrm{ml}$ improved phagocytosis of all strains. Significantly increased rates of both the ingestion and killing of one of the five strains occurred in the presence of $\operatorname{IgG}$ or in the absence of opsonins, compared to those found with each of the other four. This particular strain had significantly stronger adsorptive surface hydrophobicity than the other four strains, and with all strains there was a correlation between hydrophobicity and phagocytosis by granulocytes in the absence of opsonins.
\end{abstract}

\section{Introduction}

The recent recognition of coagulase-negative staphylococci as significant and prevalent agents in human infection has stimulated renewed interest in the biology of these micro-organisms (Colleen et al., 1980; Marrie et al., 1982; Hovelius and Mardh, 1984a; Wadström and Trust, 1984; Leighton and Little, 1986; Kasprowicz et al., 1987; Quie and Belani, 1987; Younger et al., 1987). After Escherichia coli, $S$. saprophyticus strains are the second commonest cause of non-obstructive urinary tract infections (UTI) in young, sexually active women in Europe (Wallmark et al., 1978; Jordan et al., 1980; Hovelius and Mardh, 1984b). Although bacteraemia due to $S$. saprophyticus is uncommon, UTI complicated by pyelonephritis and sepsis has been reported with or without evidence of obstructive uropathy or recurrent UTI (Olafsen and Melby, 1986; Lee et al., 1987; Golledge, 1988).

Recent studies on the physicochemical surface properties of $S$. saprophyticus in relation to adher-

Received 27 Oct. 1989; accepted 30 Oct. 1989.

* Present address: Children's Hospital of Philadelphia, Infectious Diseases and Immunology Division, 34th and Civic Center Blvd, Philadelphia, PA 19104, USA. ence to uroepithelial cells suggested that bacterial colonisation may be controlled by the interaction of specific adhesins on the bacteria with receptor structures on the host cells (Jones, 1977; Colleen et al., 1980). Bacterial cell-surface hydrophobicity and specific haemagglutinins, by mediating the interaction between the pathogen and the epithelium, may be key determinants of successful colonisation of the urinary tract (Colleen et al., 1980; Hovelius and Mardh, 1984b; Wadström and Trust, 1984). The proposed role of these surface structures is supported by the finding that the great majority of S. saprophyticus strains isolated from urine agglutinate sheep erythrocytes in a standard slide or microtitration-tray assay (Wadström and Trust, 1984; Wadström and Rozgonyi, 1986).

Since the first reported cases of UTI caused by coagulase-negative micrococci (Pereira, 1962; Mitchell, 1968), many publications have described the diagnostic and therapeutic approaches to infections with $S$. saprophyticus, but the nature of the specific and nonspecific immune responses to these organisms has remained largely unexplored. In a recent study, Hovelius and Mardh (1984a) found that $S$. saprophyticus coated with specific IgM, IgG or IgA antibodies were detected respec- 
tively, in 21, 20 and 9 of 28 infected urine specimens. Information regarding the interaction of unopsonised $S$. saprophyticus strains with circulating phagocytic cells does not exist at present, and the opsonin-dependent ingestion of these bacteria by granulocytes has not been reported.

The aim of the present study was to identify the extracellular opsonins required by human peripheral blood granulocytes for the phagocytosis and subsequent killing of $S$. saprophyticus. The role of bacterial cell-surface hydrophobicity in the interaction of granulocytes with unopsonised and antibody-opsonised cocci was also studied.

\section{Materials and methods}

\section{Bacterial strains}

Five strains of $S$. saprophyticus isolated from five different patients were examined (table I). They were identified by standard microbiological tests (Kloos and Schleifer, 1975; Akatov et al., 1981). After primary isolation, bacteria were subcultured on nutrient agar slopes, incubated overnight at $37^{\circ} \mathrm{C}$, and stored at $4^{\circ} \mathrm{C}$. Strains were subcultured on fresh agar slopes weekly. Prior to the phagocytic and killing experiments, bacteria were cultured overnight in Nutrient Broth (Oxoid) at $37^{\circ} \mathrm{C}$, then harvested by centrifugation at $1500 \mathrm{~g}$ for 10 min followed by two washes in Krebs-Ringer phosphate buffer containing glucose $0.25 \%$ (KRPD); they were resuspended at a final concentration of $10^{7}$ bacteria $/ \mathrm{ml}$. Gelatin $0.1 \%$ was added to the KRPD to enhance viability and decrease aggregation of cocci. Immediately before use the bacterial suspension was thoroughly vortex mixed (IKA-VIBRIO-FIX, IKA-Werk, Staufen, FRG).

\section{Preparation of human serum}

Normal human serum (NHS) was prepared under aseptic conditions from blood collected from six healthy adults, four men and two women aged 21-26y. The blood donors had no history of UTI. The serum was stored at $-40^{\circ} \mathrm{C}$ in small volumes, and the same pool of serum was used throughout the study. Heat-inactivated serum (HIS) was prepared by heating serum for $30 \mathrm{~min}$ at $56^{\circ} \mathrm{C}$.

\section{Immunoglobulin preparation}

To determine the phagocytosis-promoting activity of IgG immunoglobulins, opsonophagocytosis assays were performed in parallel with either a commercially available intravenous IgG (IVIG) concentrate (Sandoglobulin ${ }^{\circledR}$; SANDOZ AG, Basel) or with HIS. Experiments were performed with IVIG $1 \mathrm{mg} / \mathrm{ml}$ as a source of opsonin to equal approximately the concentration of $\operatorname{IgG}$ in HIS.

\section{Collection and separation of granulocytes}

Heparinised $(10 \mathrm{U} / \mathrm{ml})$ venous blood was obtained from healthy adult volunteers. Granulocytes were isolated by centrifugation on Ficoll-Hypaque density gradients, followed by dextran sedimentation, according to the method of Boyum (1968). Purified granulocytes were resuspended in KRPD at a final concentration of $10^{7}$ cells $/ \mathrm{ml}$. After isolation, more than $96 \%$ of the granulocytes excluded trypan blue.

\section{Phagocytosis assay}

Phagocytosis of bacteria was determined by measuring the reduction in the number of viable extracellular microorganisms after incubation of $5 \times 10^{6}$ granulocytes $/ \mathrm{ml}$ with $5 \times 10^{6}$ bacteria/ml for $60 \mathrm{~min}$ in the presence or absence of opsonins (Maródi et al., 1983). Phagocytosis assays were performed at $37^{\circ} \mathrm{C}$ with rotation at $4 \mathrm{rpm}$ (Maródi et al., 1983). Samples were removed from the phagocytic mixture for evaluation at 0 and $60 \mathrm{~min}$. Extracellular bacteria were separated from the granulocytes by differential centrifugation for $6 \mathrm{~min}$ at $75 \mathrm{~g}$ (Maródi et al., 1983). Colony counts of viable bacteria in

Table I. Origin and antibiotic sensitivity of the S. saprophyticus strains tested

\begin{tabular}{|c|c|c|c|c|c|c|c|c|c|c|c|}
\hline \multirow{2}{*}{$\begin{array}{c}\text { Strain } \\
\text { no. }\end{array}$} & \multirow[b]{2}{*}{ Specimen } & \multirow{2}{*}{$\begin{array}{c}\text { Clinical } \\
\text { diagnosis }\end{array}$} & \multicolumn{9}{|c|}{ Antibiotic sensitivity pattern* } \\
\hline & & & pen & met & oxa & $\operatorname{cpx}$ & ery & ole & nit & $\mathrm{ctm}$ & van \\
\hline 1 & Urine & Prostatitis & $\mathbf{R}$ & $S$ & $\mathrm{~S}$ & S & S & S & $S$ & $\mathrm{~S}$ & $\mathbf{S}$ \\
\hline 2 & Urine & $\begin{array}{l}\text { Chronic } \\
\text { pyelonephritis }\end{array}$ & S & $S$ & $\mathrm{~s}$ & S & S & $\mathbf{S}$ & S & S & S \\
\hline 3 & Wound & Burn & $\mathbf{R}$ & $\mathbf{R}$ & $\mathbf{R}$ & $\mathbf{R}$ & $\mathbf{R}$ & I & ND & ND & $\mathrm{S}$ \\
\hline 4 & $\begin{array}{l}\text { Peritoneal } \\
\text { fluid }\end{array}$ & $\begin{array}{l}\text { Acute } \\
\text { pancreatitis }\end{array}$ & $\mathbf{R}$ & $\mathbf{R}$ & $\mathbf{R}$ & ND & ND & $\mathbf{R}$ & $\mathrm{S}$ & $\mathbf{R}$ & $\mathrm{S}$ \\
\hline 5 & Urine & $\begin{array}{l}\text { Acute } \\
\text { cystitis }\end{array}$ & $\mathrm{S}$ & $\mathrm{S}$ & S & ND & ND & $\mathbf{R}$ & $\mathrm{S}$ & $\mathbf{R}$ & $\mathrm{S}$ \\
\hline
\end{tabular}

\footnotetext{
* Determined by standard disk diffusion method: pen, penicillin G; met, methicillin; oxa, oxacillin; cpx, cephalexin; ery, erythromycin; ole, oleandomycin; nit, nitrofurantoin; ctm, co-trimoxazole; van, vancomycin; $R$, resistant; $S$, sensitive; I, intermediate; ND, not determined.
} 
the supernate were then determined. Phagocytosis at a given time was expressed as the percentage reduction in the initial number of the viable extracellular microorganisms.

\section{Bacterial killing assay}

Freshly isolated granulocytes and an overnight broth culture of bacteria were washed and suspended in KRPD in a bacterium:cell ratio of $1: 1$, with a final cell concentration of $5 \times 10^{6} / \mathrm{ml}$. The phagocytic mixture was incubated at $37^{\circ} \mathrm{C}$ with slow rotation $(4 \mathrm{rpm})$ in the presence or absence of opsonins. Samples were removed at 0 and $60 \mathrm{~min}$ and assayed for viable bacteria. Granulocytes were lysed by adding distilled water containing bovine albumin $0.01 \%$ and mixing for $1 \mathrm{~min}$. Bacterial killing was expressed as the percentage reduction in the initial number of viable bacteria.

\section{Bacterial cell-surface hydrophobicity}

A salt aggregation test and a hydrophobic interaction chromatography assay were used to determine the degrees of bacterial aggregation and adsorptive cell-surface hydrophobicity (Rozgonyi et al., 1985; Smyth et al., 1978). The salt aggregation test was performed by mixing one drop of fresh bacterial suspension $\left(5 \times 10^{9}\right.$ bacteria) $\mathrm{ml}$ ) with one drop of increasing concentrations of ammonium sulphate solution $(0.01-4.0 \mathrm{M})$ in $0.02 \mathrm{M}$ sodium phosphate buffer ( $\mathrm{pH} 6.8$ ) with methylene blue (Rozgonyi et al., 1985). The lowest salt concentration at which aggregation of bacteria occurred was taken as a measure of the aggregating hydrophobicity of the strain.

Absorptive hydrophobicity of bacteria was determined by hydrophobic interaction chromatography as described by Smyth et al. (1978). Chromatography was performed with octyl-sepharose CL-4B gel (Pharmacia Fine Chemicals, Uppsala, Sweden). Bacterial suspensions were allowed to drain into the gel beds and the gel was washed with $5 \mathrm{ml}$ of $0.02 \mathrm{M}$ sodium phosphate buffer in an attempt to release those bacteria that had adsorbed to the hydrophobic gel. Adsorptive hydrophobicity was expressed as the percentage of bacteria adhering to the gel after elution with buffer.

\section{Statistical analysis}

To determine the statistical significance of the differences, the paired $t$ test was used (Armitage, 1971).

\section{Results}

Phagocytosis of S. saprophyticus by granulocytes in the presence and absence of opsonins

Phagocytosis of $S$. saprophyticus strains by granulocytes at a bacterium:granulocyte ratio of $1: 1$ was rapid in the presence of NHS, resulting in a decrease in the number of viable extracellular bacteria by more than $90 \%$ after incubation for 60 min (table II). In control experiments, a suspension of $5 \times 10^{6}$ bacteria/ml in KRPD was incubated with NHS $10 \%$ to measure the possible bactericidal effect of serum. The number of viable bacteria increased during the $60-\mathrm{min}$ incubation period in all cases, proving that the results could not be due to bactericidal effects of the serum in the phagocytic mixture.

When HIS was used, the degree of phagocytosis was lower than that with the same concentration of the unheated NHS, but higher for all strains than in the absence of serum opsonins (table II). In the experiments with IVIG as a source of opsonin, phagocytosis was equally effective in the presence of HIS $10 \%$ or IVIG $1 \mathrm{mg} / \mathrm{ml}$ (table II).

Incubation of $S$. saprophyticus with granulocytes in the absence of serum resulted in a small decrease in the number of viable extracellular bacteria with strains 2 and 3; with strain 1, the initial number of viable extracellular bacteria decreased by $53 \mathrm{SD} 6 \%$ after 60 mins. The differences were statistically significant $(p<0.001)$ when phagocytosis values for strain 1 were compared with those for any other strain. Incubation of granulocytes with strains 4 or 5 gave negligible decreases in the numbers of viable extracellular bacteria (table II). These findings could not be related to differences in the aggregation of the five bacterial strains in the phagocytic mixture when checked microscopically. Values of aggregating hydrophobicity were also the same for the five strains, excluding the possibility of a faster decrease of colony forming units during incubation due to aggregation of the bacteria (table IV).

In-vitro growth of the five strains in suspension

Table II. Phagocytosis of $S$. saprophyticus strains by granulocytes in the presence and absence of extracellular opsonins

\begin{tabular}{c|cccc}
\hline & \multicolumn{4}{|c}{ Mean (SD)* percentage of bacteria phagocytosed } \\
after incubation for 60 min
\end{tabular}

NHS, normal human serum; HIS, heat-inactivated serum; IVIG, intravenous IgG.

* All data represent the mean (SD) of at least 10 experiments. 
in the absence of phagocytes did not differ significantly during incubation for $60 \mathrm{~min}$ at $37^{\circ} \mathrm{C}$ at $4 \mathrm{rpm}$, indicating that decreases in the numbers of viable bacteria were due to interactions of phagocytic cells with micro-organisms, and were not influenced by differences in bacterial growth.

\section{Killing of $S$. saprophyticus by granulocytes in the presence and absence of opsonins}

Incubation of granulocytes with any of the $S$. saprophyticus strains in the presence of NHS $10 \%$ gave a rapid decrease in the total numbers of extracellular and intracellular bacteria, determined by lysis of the phagocytic cells at 0 and $60 \mathrm{~min}$ (table III). To investigate the effect of HIS on the killing of $S$. saprophyticus strains, bacteria were incubated for $60 \mathrm{~min}$ in the presence of HIS $10 \%$ at $37^{\circ} \mathrm{C}$ with rotation. HIS promoted a lower rate of killing than did the same concentration of fresh serum for all of the strains (table III). After $60 \mathrm{~min}$, the percentage decrease of the total number of bacteria incubated with granulocytes and IVIG $(1 \mathrm{mg} / \mathrm{ml}$ ) was similar to that found with HIS $10 \%$. The killing values for strain 1 were significantly higher than those for the other strains when HIS or IVIG was used to opsonise the bacteria $(p<0.001)$. When the killing assay was performed in the absence of opsonins strains 4 and 5 were still viable after $60 \mathrm{~min}$ (table III). Incubation of granulocytes with strains 1, 2 and 3 resulted in various decreases in the total number of bacteria, reflecting differences in the degree of ingestion (tables II and III).

\section{Bacterial cell-surface hydrophobicity}

Data on cell-surface hydrophobicity determined by salt aggregation and by hydrophobic interaction

Table III. Killing of $S$. saprophyticus strains by granulocytes in the presence and absence of extracellular opsonins

\begin{tabular}{|c|c|c|c|c|}
\hline \multirow[b]{2}{*}{$\begin{array}{c}\text { Strain } \\
\text { no. }\end{array}$} & \multicolumn{4}{|c|}{$\begin{array}{l}\text { Mean (SD) percentage of bacteria killed after } \\
\text { inoculation for } 60 \mathrm{~min}\end{array}$} \\
\hline & $\begin{array}{l}\text { with } \\
\text { NHS } 10 \%\end{array}$ & $\begin{array}{l}\text { with } \\
\text { HIS } 10 \%\end{array}$ & $\begin{array}{c}\text { with } \\
\text { IVIG } 1 \mathrm{mg} / \\
\mathrm{ml}\end{array}$ & $\begin{array}{l}\text { without } \\
\text { opsonins }\end{array}$ \\
\hline 1 & $89(9)$ & $44(10)$ & $49(9)$ & $38(4)$ \\
\hline 2 & $84(8)$ & $21(7)$ & $21(5)$ & $11(3)$ \\
\hline 3 & $87(8)$ & $22(4)$ & $19(4)$ & $12(4)$ \\
\hline 4 & $88(5)$ & $17(5)$ & $16(4)$ & $0 \cdot 2(0 \cdot 1)$ \\
\hline 5 & $83(5)$ & $17(5)$ & $16(6)$ & $0.2(0.2)$ \\
\hline
\end{tabular}

* Killing of bacteria was expressed as the percentage decrease in the initial number of viable micro-organisms. chromatography are summarised in table IV. Aggregating hydrophobicity values in ammonium sulphate solutions were similar for all strains. However, with hydrophobic interaction chromatography to quantitate adsorptive cell-surface hydrophobicity, a significant difference between strain 1 and the remainder of the strains was found. Adsorption of strain 1 organisms to the hydrophobic ligands was stronger, resulting in less than $10 \%$ recovery from the gel. Close correlation for the five strains between bacterial cell-surface hydrophobicity and phagocytosis by granulocytes in the absence of extracellular opsonins is shown in the figure.

\section{Discussion}

The results of this study demonstrated that five different strains of $S$. saprophyticus were equally and adequately opsonised by pooled NHS for phagocytosis and killing by granulocytes. To determine whether the high rate and degree of phagocytosis and killing depended primarily on immunoglobulins or on the combined activities of both heat stable and heat labile opsonins, parallel phagocytic and killing experiments were performed. The results showed that neither HIS nor IVIG was sufficient for optimal phagocytosis and killing. Previous investigations conducted by Pascual et al. (1987) demonstrated that 22 of 38 clinical isolates of $S$. epidermidis did not require complement for efficient uptake by granulocytes in suspension. These bacteria were significantly less hydrophobic than the 16 isolates that required complement and IgG for adequate opsonisation (Pascual et al., 1987). The $S$. saprophyticus strains tested in our study gave opposite results.

Strain 1 was phagocytosed and killed by granulocytes more effectively than the other strains when HIS was used as a source of opsonins; this may have been due to differences in the concentration of specific antibodies against this particular strain in pooled adult sera. However, the theory was disproved as experiments with IVIG concentrate prepared from thousands of blood donations gave similar results.

Marked differences amongst the five bacterial strains became apparent when phagocytosis experiments were performed in the absence of opsonins. Results suggested that susceptibility to phagocytosis by granulocytes might correlate with surface hydrophobicity of these bacteria. Indeed, we demonstrated by hydrophobic interaction chromatography that strains possessing stronger adsorptive cell-surface hydrophobicity associated with granulocytes in considerably higher proportion. Expres- 
Table IV. Hydrophobic surface properties of $S$. saprophyticus strains

\begin{tabular}{c|cc}
\hline $\begin{array}{c}\text { Strain } \\
\text { no. }\end{array}$ & $\begin{array}{c}\text { Salt aggregation } \\
\text { test* }\end{array}$ & $\begin{array}{c}\text { Hydrophobic interaction } \\
\text { chromatography }\end{array}$ \\
\hline 1 & $1 \cdot 5(0 \cdot 2)$ & $92(4)$ \\
2 & $1 \cdot 4(0 \cdot 3)$ & $37(3)$ \\
3 & $1 \cdot 4(0 \cdot 2)$ & $38(7)$ \\
4 & $1 \cdot 5(0 \cdot 3)$ & $16(5)$ \\
5 & $1 \cdot 5(0 \cdot 3)$ & $22(8)$ \\
\hline
\end{tabular}

*Values are the lowest ammonium sulphate concentration (mol/ $L)$ in which bacterial aggregation occurred.

$\dagger$ Values are the percentage of bacteria adhering to octylsepharose CL-4b gel after elution with $0.02 \mathrm{M}$ sodium phosphate buffer ( $\mathrm{pH} \mathrm{6.8).}$

All data represent the mean (SD) of at least four experiments.

sion of selective bacterial surface antigens, and, occasionally surface hydrophobicity, are affected by growth conditions such as frequency of passage in artificial media and the nutrient environment (Adlam et al., 1969). In the present study, specific media used for the passage of the bacterial strains and the number of passages were standardised.

The relationship between pathogenicity and adhesion of bacteria to mucous membranes is well documented (Jones, 1977; Evans et al., 1978;
Gibbons and Qureshi, 1978; Wadström and Trust, 1984; Rozgonyi et al., 1985; Lindahl et al., 1986; Kasprowicz et al., 1987; Quie and Belani, 1987). It has been proposed that the surface haemagglutinins of $S$. saprophyticus are important virulence determinants that allow the pathogen to colonise the non-obstructed urinary tract (Colleen et al., 1980; Wadström and Rozgonyi, 1986). These surface structures have strong similarities with haemagglutinating fimbriae of uropathogenic $E$. coli and other gram-negative bacteria associated with UTI, and can be classified as hydrophobic surface lectins of pathogens of mucosal surfaces (Wadström and Trust, 1984; Wadström and Rozgonyi, 1986). Similar surface structures may be involved in the interaction of bacteria with phagocytic cell membranes; thus, the capacity of certain strains of $S$. saprophyticus for adherence to receptors on uroepithelial cells may be necessary for infection. However, the same property may enhance both nonopsonic and IgG-mediated phagocytosis.

This work was partly supported by grants ETT-6 and ETT-3 from the Hungarian Ministry of Health and partly by grant OTKA-712 from the Hungarian Academy of Sciences. We appreciate the technical assistance of Mrs Ildikó Gyarmati and Mrs Erzsebet Papp-Falusi and we thank Ms Marie McVeigh and Ms Judit Posta for their help in preparing the manuscript.

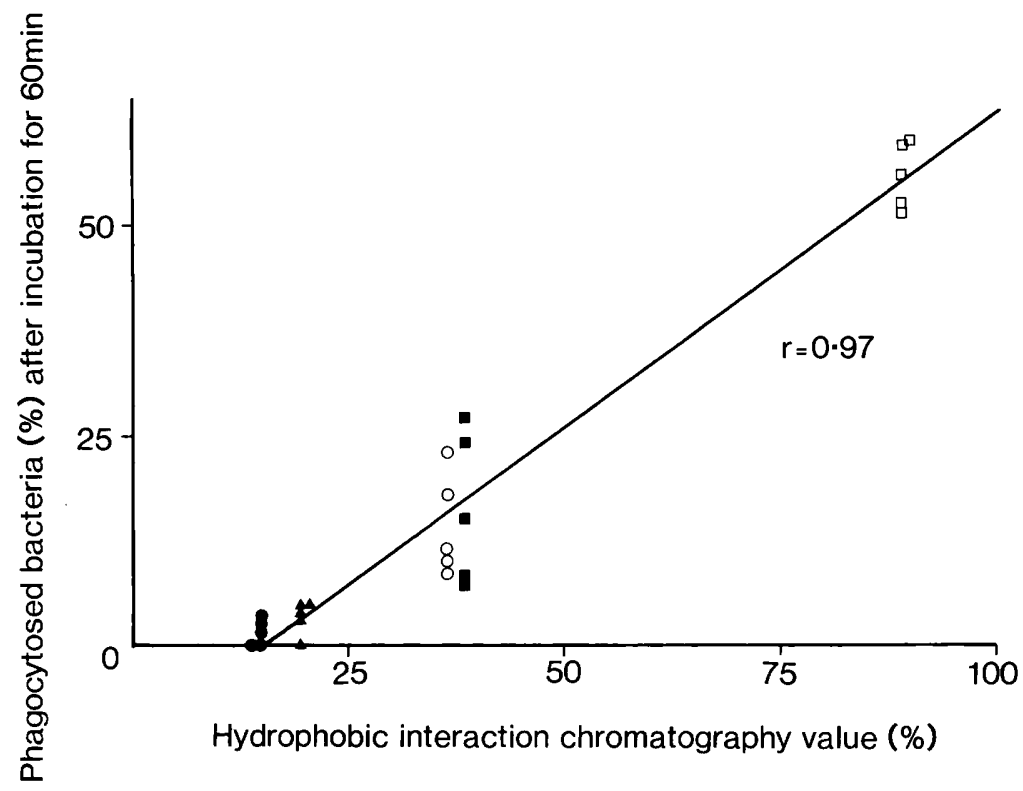

Figure. Correlation between surface hydrophobicity and phagocytosis by granulocytes of $S$. saprophyticus strains (calculated by the least squares method). Phagocytosis experiments were performed in parallel on the same days in the absence of extracellular opsonins: $\mathbf{O}$, strain $1 ; \mathbf{\Delta}, 2 ; \bigcirc, 3 ; \mathbf{\square}, 4 ; \square, 5$. 


\section{REFERENCES}

Adlam C, Pearce J H, Smith H 1970 The interaction of staphylococci grown in vivo and in vitro with polymorphonuclear leucocytes. Journal of Medical Microbiology 3: 157163.

Akatov A K, Khatenever M L, Devriese C A 1981 Identification of coagulase-negative staphylococci isolated from clinical source. Zentralblatt für Bakteriologie, Mikrobiologie und Hygiene 1: Abt Suppl. 10: 153-161.

Armitage P 1971 Statistical methods in medical research. Blackwell Scientific Publications, Oxford.

Boyum A 1968 Isolation of mononuclear cells and granulocytes from human blood. Isolation of mononuclear cells by one centrifugation and of granulocytes by combining centrifugation and sedimentation at $1 \mathrm{~g}$. Scandinavian Journal of Laboratory and Clinical Medicine 21 Suppl 97: 77-89.

Colleen S, Herström P, Wieslander A, Mardh P A 1980 Physicochemical properties of Staphylococcus epidermidis and Staphylococcus saprophyticus as studied by aqueous polymer two-phase systems. Scandinavian Journal of Infectious Diseases Suppl 24: 165-172.

Evans D G, Evans D J, Tjoa W S, DuPont H L 1978 Detection and characterization of colonization factor of enterotoxigenic Escherichia coli isolated from adults with diarrhea. Infection and Immunity 19: 727-736.

Gibbons R J, Qureshi J V 1978 Selective binding of blood groupreactive salivary mucins by Streptococcus mutans and other oral organisms. Infection and Immunity 22: 665-671.

Golledge C L 1988 Staphylococcus saprophyticus bacteremia. Journal of Infectious Diseases 157: 215.

Hovelius B, Mardh P A $1984 a$ Antibody-coating and haemagglutination by Staphylococcus saprophyticus. Acta Pathologica Microbiologica et Immunologica Scandinavica 93: 3740.

Hovelius B, Mardh P A 1984 b Staphylococcus saprophyticus as a common cause of urinary tract infections. Reviews of Infectious Diseases 6: 328-337.

Jones G W 1977 The attachment of bacteria to the surfaces of animal cells. In: Reissig J L (ed) Microbial interactions (Receptor and recognition series B). Chapman and Hall, London, pp 139-164.

Jordan P A, Iravani A, Richard G A, Baer H 1980 Urinary tract infection caused by Staphylococcus saprophyticus. Journal of Infectious Diseases 142: 510-515.

Kasprowicz A, Bialecka A, Heczko P B 1987 Surface properties of Staphylococcus saprophyticus strains isolated from various sources. Zentralblatt für Bakteriologie, Mikrobiologie und Hygiene I: Abteilung Suppl 16: 77-81.

Kloos W E, Schleifer K H 1975 Simplified scheme for routine identification of human Staphylococcus species. Journal of Clinical Microbiology 1 : 82-88.

Lee W, Carpenter R J, Phillips L E, Faro S 1987 Pyelonephritis and sepsis due to Staphylococcus saprophyticus. Journal of Infectious Diseases 155: 1079-1080.

Leighton P M, Little J A 1986 Identification of coagulasenegative staphylococci isolated from urinary tract infections. American Journal of Clinical Pathology 85: 92-95.
Lindahl M, Brossmer R, Wadström T 1986 Sialic acid and Nacetyl-galactosamine specific bacterial lectins of enterotoxigenic Escherichia coli (ETEC). In: Wu A M (ed) Lectins. Plenum Press, Stockholm, pp 55-68.

Maródi L, Leijh P C J, van Furth R 1983 A micromethod for the separate evaluation of phagocytosis and intracellular killing of Staphylococcus aureus by human monocytes and granulocytes. Journal of Immunological Methods 57: 353361 .

Marrie T J, Kwan C, Noble M A, West A, Duffield L 1982 Staphylococcus saprophyticus as a cause of urinary tract infections. Journal of Clinical Microbiology 16: 427-431.

Mitchell R G 1968 Classification of Staphylococcus albus strains isolated from the urinary tract. Journal of Clinical Pathology 21 : 93-96.

Olafsen L D, Melby K 1986 Urinary tract infection with septicaemia due to Staphylococcus saprophyticus in a patient with a ureteric calculus. Journal of Infection 13: 92-93.

Pascual A, Fleer A, Westerdaal N A C, Berghuis M, Verhoef J 1987 Surface hydrophobicity and opsonic requirements of coagulase-negative staphylococci in suspension and adhering to a polymer substratum. European Journal of Clinical Microbiology and Infectious Diseases 7: 161-166.

Pereira A T 1962 Coagulase-negative strains of staphylococcus possessing antigen 51 as agents of urinary tract infections. Journal of Clinical Pathology 15 : 252-253.

Quie P G, Belani K K 1987 Coagulase-negative staphylococcal adherence and persistence. Journal of Infectious Diseases 156: $543-547$.

Rozgonyi F, Szitha K R, Ljungh A, Baloda S B, Hjertén S, Wadström $T 1985$ Improvement of the salt aggregation test to study bacterial cell-surface hydrophobicity. FEMS Microbiology Letters 30: 131-138.

Smyth C J et al. 1978 Differences in hydrophobic surface characteristics of porcine enteropathogenic Escherichia coli with or without $\mathrm{K} 88$ antigen as revealed by hydrophobic interaction chromatography. Infection and Immunity $\mathbf{2 2}$ : 462-472.

Wadström T, Trust T J 1984 Bacterial surface lectins. In: Jeljaszewicz J, Easmon C S F (eds) Medical microbiology. Academic Press, London, pp 287-334.

Wadström T, Rozgonyi F 1986 Virulence determinants of coagulase-negative staphylococci. In: Mardh P A, Schleifer K H (eds) Coagulase-negative staphylococci. Almqvist and Wiksell International, Stockholm, pp 123-130.

Wallmark G, Arremark I, Telander B 1978 Staphylococcus saprophyticus: a frequent cause of urinary tract infection among female outpatients. Journal of Infectious Diseases 138: 791-797.

Younger J J, Christensen G D, Bartley D L, Simmons J C H, Barrett F F 1987 Coagulase-negative staphylococci isolated from cerebrospinal fluid shunts: importance of slime production, species identification, and shunt removal to clinical outcome. Journal of Infectious Diseases 156: 548554. 